\title{
Reliability Analysis and Maintainability for the Design of Grid and Hybrid Solar Power Plant Systems in Wonogiri Regency
}

\author{
Etika Nur'Aini ${ }^{1 *}$, Rachmawan Budiarto $^{2)}$, Bakti Setiawan ${ }^{3)}$ and Alfian Ma'arif ${ }^{4)}$
}

\author{
1) Magister of Engineering System, Faculty of Engineering Universitas Gadjah Mada \\ ${ }^{2)}$ Department of Nuclear Engineering and Engineering Physics, Faculty of Engineering Universitas Gadjah Mada \\ 3) Department of Architecture and Planning, Faculty of Engineering Universitas Gadjah Mada \\ 4) Electrical Engineering Studies Program, Universitas Ahmad Dahlan \\ Corresponding Email: *) etika.nuraini@mail.ugm.ac.id
}

\begin{abstract}
Indonesia has the potential for large solar power plants. It has relatively constant solar radiation because it is close to the equator. Besides, solar energy includes renewable energy that is more environmentally friendly and easier to apply in office areas, especially Wonogiri. However, it turns out that the solar power plant projects that have been built are not yet fully functional, and some have even failed. A lack of responsibility and maintenance causes this carried out after the project is complete. For this reason, it is necessary to estimate the reliability of these components and determine the maintenance schedule before the project is carried out. So that later they have a picture and be better prepared when this project is already underway. The fault tree method's failure factors are expected to create a picture to maintain reliability and determine the prioritized components for maintainability. For the results obtained to be more appropriate, apart from seeing the quantitative analysis output, the fault tree also needs to be adjusted to the component manual or datasheet to determine the replacement of spare parts and their maintenance. So that the resulting schedule for maintenance and replacement of spare parts. Thus, the solar power plant project that has been built will be more reliable and can be appropriately utilized.
\end{abstract}

Keywords: Solar power plant, renewable energy, fault tree, reliability, maintainability.

\section{INTRODUCTION}

In terms of 23 Projects in 17 renewable energy development countries, it was found that almost $21 \%$ of projects failed, and only $48 \%$ were fully functional. This is due to lack of responsibility and care, low quality/technology used, external influences (political, institutional, environmental) [1]. For the designed generator technology to continue to provide sustainable benefits, it is necessary to have a good design and maintain its capability or reliability. Several factors influence a Solar Power Plant's reliability: the components used, minimizing technical errors, and implementing continuous maintenance mechanisms. Several methods can be used to assess reliability to reduce failures, namely by risk analysis, which is carried out by applying the reliability technique of loss impact analysis
(Failure Mode and Effects Analysis (FMEA)) and fault tree analysis. The PV (Photovoltaic) module's failure can cause a reduction in power from the operation and cause safety or security issues to be resolved [2].

There are not many papers that discuss the reliability of PV systems, especially with hybrid systems, most grid systems, and it is not detailed until the maintenance schedule is combined from reliability and is adjusted per component. [3]. For example, an analysis of reliability, availability, and maintenance was carried out by A. Sayed, M. El-Shimy, M. El-Metwally, and M. Elshahed in a grid PV system [4]. Using failure and repair rate data for PV systems obtained from literature then assess the reliability for wiring systems, inverters, PV modules, converters, storage. The analysis of the estimated age of the converter, wiring system, inverter, and storage system is $30.77,19.21,8.3$, and 10.31 years, respectively.

The reliability of PV with a grid system on a larger scale has been studied by Gabriele Zini, Christophe Mangeant, and Jens Merten using the FTA (fault tree analysis) method. Large scale grid analysis assumes that wiring is not accounted for in failures, so the installation is considered acceptable, so it only focuses on electrical/electronic component failures with 20 years with an average of 8.5 hours of operation a day. All components in a PV system are connected in series. The result is after one year for $100 \mathrm{kWp}$ probability without failure is $97.79 \%$, while the inverter only $88.25 \%$. For 2.5 MWp, the probability without failure is $57.36 \%$, while the 24 inverters $4.98 \%$. Moreover, for $2.5 \mathrm{MWp}$ systems, errors will be experienced up to a $99 \%$ probability of failure in PV modules, string protection, inverters, and AC (Alternating Current) circuit breakers [3].

The reliability value is strongly influenced by the length of operation so that the system battery backup is essential in photovoltaic systems [5]. For this reason, it will also be analyzed when it is designed using a hybrid approach. In general, hybrid, namely, electricity, is based on renewable energy combined with fossil electricity generation [6]. In this research, the hybrid system is a system that is connected like a grid or connected to a state electricity company, and there is storage for storing 
energy from the solar power plant.

The FTA method was chosen because it can analyze related reliability, but it is also used to estimate reliability [7]. In this study, the system will be made a fault tree per component to detail the errors that can cause this component to be damaged. The actual number of components used is not counted because to see error details per element. The PV system to be analyzed is connected hybrid or grid. Then it is calculated to see the maintenance schedule needed. It will also be adjusted to the tool datasheet to produce a design schedule used as a reference for component maintenance.

\section{METHODOLOGY}

\section{A. Fault Tree}

A condition is reliable if an item's probability is to perform a predetermined function under certain operating conditions and environments for a predetermined period. So that the above definition can be divided into four components:

1. The probability of failing slightly without experiencing failure

2. Adequate and good performance

3. Time according to the predetermined (mission time)

4. The operating conditions are in good shape

To reduce failure, it is necessary to carry out a reliability analysis. Part of the risk analysis is generally carried out by applying the fault tree analysis. Fault Tree Analysis (FTA) is used as a technique to identify the failure of a system. FTA is function-oriented or better known as the "top-down approach," because this analysis starts at the system level (top) and continues downward. This analysis's starting point identifies functional failure modes at the top level of a system or subsystem. Besides being used for qualitative failure analysis, FTA can also be used for quantitative failure analysis [8][9]. Failure itself can be defined as the interruption of an item's ability, from a component to a complex system, to carry out its function. The failure of a part can be classified into three groups:

1. Primary failure

2. A component is in a damaged state (non-working state) where it is calculated that it will fail, so it is necessary to take corrective action to return to a working condition. Primary failure of the component will occur in the design envelope of the element, and the cause of this failure is the life of the component. Secondary failure occurs beyond calculation.

3. Command faults, components are non-working due to control signal errors or noise; often, corrective action is not needed to restore parts to their original state [10]

Knowing the solar power plant's function and the consequences if it experiences a failure, it is hoped that the fault tree can minimize loss. The following is Figure 1 , the fault tree symbol used [11].

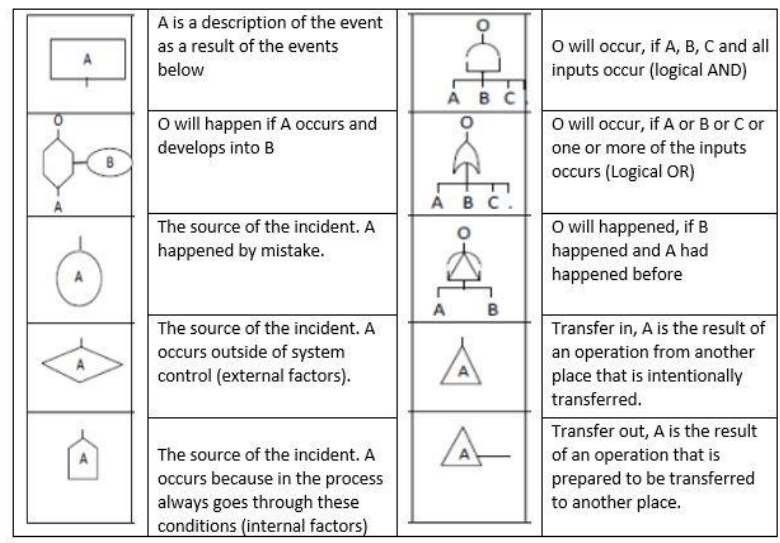

Figure 1. FTA Symbol Used

\section{B. Failure Rate}

The failure rate is the anticipated number of times the item fails within a certain period. It is a calculated value that provides a measure of reliability for a product. This value is usually expressed as failures per million hours but can also be described as the FIT (failure in time) rate of failures per billion hours. For example, if a component has a failure rate of two failures per million hours, it is anticipated that it fails twice in a one-million-hour period. [12].

Equation is [2] [13]:

$$
\begin{array}{r}
F_{(t) \cong \lambda t} \\
R(t)=1-F_{(t)}
\end{array}
$$

Where: $F(t)$ : Probability of failure $\lambda$ : failure rate, $t$ : time spent operating, $R(t)$ : realibility

The failure rate is obtained from various sources [2][4],[7],[14]-[16]. Probabilistic failure rate equation [14]:

$$
\begin{aligned}
& \text { probabilistic failure rate }=(\text { failure rate } x \\
& \text { operating hour })
\end{aligned}
$$

\section{Research Flow}

1. First, describe component Solar Panel Plant used in Wonogiri Office, operating hour that analysis, and looked datasheet / manual book each component too looked maintainability.

2. Then, the search failure rate in some literature, to get probabilistic failure rate used formula (3) from that we can get reliability used formula (2)

3. and built FTA for on Grid dan Hybrid System

4. After built FTA do quantitative analysis and which component that make failure and get reliability value is obtained.

\section{Solar Power Plant System}

The Solar Power Plant component will be different if the system is installed on a grid (Solar Power Plant connected to the State Electricity Company network), off a grid (not connected to the State Electricity Company network), or hybrid (combined on-grid and off-grid). Following are the subsystem components of the Solar Power Plant in Figure 2. The critical part of the Solar Power Plant is the photovoltaic array because it is the 
primary system that can catch solar energy, and its cost can account for about $40 \%$ of the entire system [17]. So, it is crucial to keep important and expensive parts in good condition.

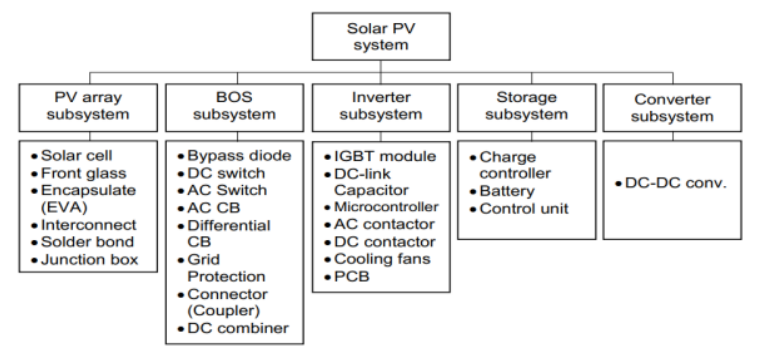

Figure 2. Subsystem from Solar PV System [7]

\section{RESULTS AND DISCUSSION}

In this study, the failure will be seen from the side of the Solar Power Plant system. All components in the PV system have two connected on-grid scenarios or directly connected to State Electricity Company. The plan for this system will install in a new complex Wonogiri Office that before not yet installed. The on-grid connection will install in some offices area and a hybrid in the "Bupati" Office. The features on the Solar Power Plant side are connected in series so that if one part fails then, all systems will fail, and another scenario is hybrid (there is a backup battery, so if the design from the on-grid fails, there is still a backup from the battery). Another assumption is:

1. Does not take into account the number of components (because you want to detail the failures per item and viewed in one system)

2. Top Event binary state

3. Non-repairable failures

4. The constant component failure rate

The following fault tree for both connections can be seen in

Figure 5. until

Figure 7. Numbers 1 and 2 for hybrid connections can be obtained from the fault tree of the on-grid connection.

Quantitative analysis for on-grid and hybrid connections, using an operation duration of 8.5 hours, with a probabilistic failure rate at Table 1 the results are as follows:

Quantitative analysis for on-grid connection:

$$
\begin{aligned}
\mathrm{T} & =2 \\
& =3+8+\mathrm{Q}+\mathrm{R}+10+13 \\
& =(4+5)+(\mathrm{G}+\mathrm{H}+\mathrm{I}+\mathrm{J}+\mathrm{K}+9)+\mathrm{Q}+\mathrm{R}+(\mathrm{S}+\mathrm{T}+\mathrm{U}+ \\
& 11+12)+(\mathrm{c}+\mathrm{d}) \\
& =((6+\mathrm{C}+\mathrm{D}+\mathrm{E}+\mathrm{F})+(7+\mathrm{C}+\mathrm{D}+\mathrm{E}+\mathrm{F}))+((\mathrm{G}+\mathrm{H}+ \\
& \mathrm{I}+\mathrm{J}+\mathrm{K}+(\mathrm{L}+\mathrm{M}+\mathrm{N}+\mathrm{O}+\mathrm{P}))+\mathrm{Q}+\mathrm{R}+((\mathrm{S}+\mathrm{T}+\mathrm{U} \\
& +(\mathrm{V}+\mathrm{W}+\mathrm{X}+\mathrm{Y}+\mathrm{Z}+\mathrm{a}+\mathrm{b})+(\mathrm{V}+\mathrm{W}+\mathrm{X}+\mathrm{Y}+\mathrm{Z}+ \\
& \mathrm{a}+\mathrm{b}))+(\mathrm{c}+\mathrm{d}) \\
& =(((\mathrm{A}+\mathrm{B})+\mathrm{C}+\mathrm{D}+\mathrm{E}+\mathrm{F})+((\mathrm{A}+\mathrm{B})+\mathrm{C}+\mathrm{D}+\mathrm{E}+ \\
\mathrm{P}(\mathrm{T}) \quad & \mathrm{F})))+((\mathrm{G}+\mathrm{H}+\mathrm{I}+\mathrm{J}+\mathrm{K}+(\mathrm{L}+\mathrm{M}+\mathrm{N}+\mathrm{O}+\mathrm{P}))+\mathrm{Q}+\mathrm{R} \\
& +((\mathrm{S}+\mathrm{T}+\mathrm{U}+(\mathrm{V}+\mathrm{W}+\mathrm{X}+\mathrm{Y}+\mathrm{Z}+\mathrm{a}+\mathrm{b})+(\mathrm{V}+\mathrm{W}+\mathrm{X}+
\end{aligned}
$$

\author{
$\mathrm{Y}+\mathrm{Z}+\mathrm{a}+\mathrm{b}))+(\mathrm{c}+\mathrm{d})$ \\ $=\mathrm{A}+\mathrm{B}+\mathrm{C}+\mathrm{D}+\mathrm{E}+\mathrm{F}+\mathrm{G}+\mathrm{H}+\mathrm{I}+\mathrm{J}+\mathrm{K}+\mathrm{L}+\mathrm{M}+\mathrm{N}+\mathrm{O}$ \\ $+\mathrm{P}+\mathrm{Q}+\mathrm{R}+\mathrm{S}+\mathrm{T}+\mathrm{U}+\mathrm{V}+\mathrm{W}+\mathrm{X}+\mathrm{Y}+\mathrm{Z}+\mathrm{a}+\mathrm{b}+\mathrm{c}+\mathrm{d}$ \\ $=0.001219059$ \\ Reliability $\quad 0.998780941$ or $99.8 \%$ \\ $\{A\},\{B\},\{C\},\{D\},\{E\},\{F\},\{G\},\{H\},\{I\}$, \\ $\{\mathrm{J}),\{\mathrm{K}\},\{\mathrm{L}\},\{\mathrm{M}\},\{\mathrm{N}\},\{\mathrm{O}\},\{\mathrm{P}\},\{\mathrm{Q}\},\{\mathrm{R}\}$, \\ $\{\mathrm{S}\},\{\mathrm{T}\},\{\mathrm{U}\},\{\mathrm{V}\},\{\mathrm{W}\},\{\mathrm{X}\},\{\mathrm{Y}\},\{\mathrm{Z}\}$, \\ Min Cut $\{\mathrm{a}\}$, \\ Set $\quad\{b\},\{c\},\{d\}$
}

When connected hybrid, there is an additional failure rate charge controller $6.4 \times 10^{-6}$, battery $11 \times 10^{-6}[4]$, and inverter. For inverters on a hybrid connection, the failure rate (e) value is $40.29 \times 10^{-6}$ [5] or $87.09 \times 10^{-6}$ (obtained from the min-cut set of the inverter grid) when using 40.29 $\mathrm{x} 10^{-6}$, the results for quantitative analysis for the hybrid connection:

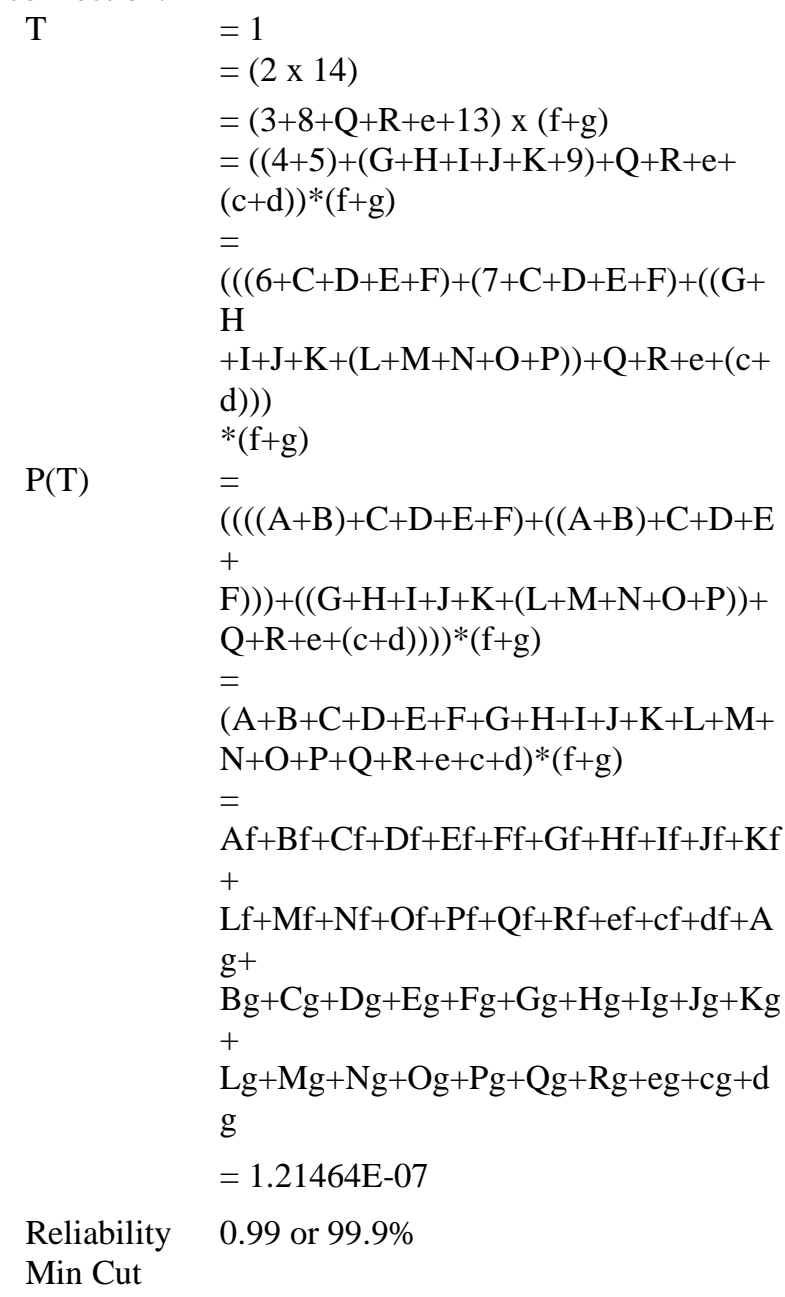

Set

$\{\mathrm{Af}\}\{\mathrm{Bf}\}$ or the completed in Table 2

Meanwhile, when using the $87.09 \times 10^{-6}$ failure rate for the inverter, the reliability will decrease even more, but it will not be noticeable when $<1$ year. If the duration is increased, namely for one year, the operation duration is still the same, 8.5 hours, so $t=3102.5$ with the failure rate value, the reliability becomes $97.6 \%$. This value is lower than the value of the lower failure rate. Thus, a 
greater failure rate will affect reliability. The following compares the probability of failure and reliability for 20 years or $\mathrm{t}=62050$ for on-grid and hybrid connections. The results can be seen in Table 3 .

From Table 3, it can be seen that the hybrid connection is more reliable than on grid. Even though it is reliable, it still requires maintenance and monitoring because the reliability decreases after one year, especially with ongrid connections. Several equipment pieces are critical because they have a greater probability of damage, such as cooling fans, control communication board (CCB), rack structure, grounding, IGBT (An insulated-gate bipolar transistor) for grid connections. Meanwhile, hybrid links such as charge controllers, batteries, rack structures, and grounding/lightning protection systems. This component needs to be prioritized to schedule maintenance, check its condition, and not rule out other equipment.

Table 1. Minimum Cut Set or Probabilistic Failure Rate for on Grid

\begin{tabular}{|c|c|c|c|}
\hline \multirow[b]{2}{*}{ No } & \multicolumn{3}{|c|}{ Grid } \\
\hline & Event & Remark & $\begin{array}{c}\text { Probabilistic } \\
\text { failure rate } \\
\text { (P) }\end{array}$ \\
\hline 1 & A & Rack Structure & 2.07E-04 \\
\hline 2 & B & $\begin{array}{l}\text { Grounding/Lighting } \\
\text { Protection System }\end{array}$ & $1.38 \mathrm{E}-04$ \\
\hline 3 & $\mathrm{C}$ & Junction Box Bypass Diode & $5.75 \mathrm{E}-06$ \\
\hline 4 & $\mathrm{D}$ & Encapsulates leakage & $3.45 \mathrm{E}-05$ \\
\hline 5 & $\mathrm{E}$ & Module & $1.29 \mathrm{E}-07$ \\
\hline 6 & $\mathrm{~F}$ & Connector & 3.83E-06 \\
\hline 7 & $\mathrm{G}$ & Fuse String & 5.35E-07 \\
\hline 8 & $\mathrm{H}$ & SMU & $1.40 \mathrm{E}-05$ \\
\hline 9 & $\mathrm{I}$ & Fuse & $0.17 \mathrm{E}-06$ \\
\hline 10 & $\mathrm{~J}$ & DC Switch & $1.7 \mathrm{E}-05$ \\
\hline 11 & $\mathrm{~K}$ & Disconnector & $0.85 \mathrm{E}-06$ \\
\hline 12 & $\mathrm{~L}$ & Metal Sleeve & 5.95E-09 \\
\hline 13 & M & Screw & $5.12 \mathrm{E}-06$ \\
\hline 14 & $\mathrm{~N}$ & Stud & 5.95E-09 \\
\hline 15 & $\mathrm{O}$ & Block & $1.24 \mathrm{E}-07$ \\
\hline 16 & $\mathrm{P}$ & Strip & 1.87E-08 \\
\hline 17 & $\mathrm{Q}$ & AC Cable Failure & $1.10 \mathrm{E}-07$ \\
\hline 18 & $\mathrm{R}$ & DC Main Cable Failure & 4.10E-07 \\
\hline 19 & $\mathrm{~S}$ & Open Component & $0.08 \mathrm{E}-05$ \\
\hline 20 & $\mathrm{~T}$ & Short Circuit & $0.085 \mathrm{E}-05$ \\
\hline 21 & $\mathrm{U}$ & Change parameter & $0.85 \mathrm{E}-06$ \\
\hline 22 & $\mathrm{~V}$ & Cooling Fan & $2.27 \mathrm{E}-04$ \\
\hline 23 & W & $\begin{array}{l}\text { Control Communication } \\
\text { Board (CCB) }\end{array}$ & $2.12 \mathrm{E}-04$ \\
\hline 24 & $\mathrm{X}$ & DC Capasitor & $0.85 \mathrm{E}-04$ \\
\hline 25 & $\mathrm{Y}$ & DC Main Breaker & $5.16 \mathrm{E}-05$ \\
\hline 26 & $\mathrm{Z}$ & IGBT & $9.38 \mathrm{E}-05$ \\
\hline 27 & $\mathrm{a}$ & AC Filter & $0.17 \mathrm{E}-04$ \\
\hline 28 & $\mathrm{~b}$ & AC Circuit Breaker & $5.16 \mathrm{E}-05$ \\
\hline 29 & $\mathrm{c}$ & Transformator & $1.71 \mathrm{E}-05$ \\
\hline 30 & d & Power Switch Gear & $0.34 \mathrm{E}-04$ \\
\hline & & tal Probability & 1.22E-03 \\
\hline
\end{tabular}

Table 2. Minimum Cut Set or Probabilistic Failure Rate for on Hybrid

\begin{tabular}{|c|c|c|c|}
\hline \multirow[b]{2}{*}{ No } & \multicolumn{3}{|c|}{ Hybrid } \\
\hline & Event & Remark & $\begin{array}{c}\text { Probabilistic } \\
\text { failure rate }(\mathrm{P})\end{array}$ \\
\hline 1 & Af & $\begin{array}{l}\text { Rack Structure AND Charge } \\
\text { Controller (CC) }\end{array}$ & $1.13 \mathrm{E}-08$ \\
\hline 2 & $\mathrm{Bf}$ & $\begin{array}{l}\text { Grounding/Lightning } \\
\text { Protection System AND } \\
\text { (CC) }\end{array}$ & 7.49E-09 \\
\hline 3 & $\mathrm{Cf}$ & $\begin{array}{l}\text { Junction Box Bypass Diode } \\
\text { AND (CC) }\end{array}$ & $3.13 \mathrm{E}-10$ \\
\hline 4 & Df & $\begin{array}{l}\text { Encapsulates leakage AND } \\
\text { (CC) }\end{array}$ & $1.88 \mathrm{E}-09$ \\
\hline 5 & $\mathrm{Ef}$ & Module AND (CC) & $7.02 \mathrm{E}-12$ \\
\hline 6 & $\mathrm{Ff}$ & Connector AND (CC) & $2.08 \mathrm{E}-10$ \\
\hline 7 & Gf & Fuse String AND (CC) & $2.91 \mathrm{E}-11$ \\
\hline 8 & Hf & SMU AND (CC) & $7.63 \mathrm{E}-10$ \\
\hline 9 & If & Fuse AND (CC) & $9.25 \mathrm{E}-12$ \\
\hline 10 & Jf & DC Switch AND (CC) & $9.25 \mathrm{E}-10$ \\
\hline 11 & $\mathrm{Kf}$ & Disconnector AND (CC) & $4.62 \mathrm{E}-11$ \\
\hline 12 & $\mathrm{Lf}$ & Metal Sleeve AND (CC) & $3.24 \mathrm{E}-13$ \\
\hline 13 & Mf & Screw AND (CC) & $2.79 \mathrm{E}-10$ \\
\hline 14 & $\mathrm{Nf}$ & Stud AND (CC) & $3.24 \mathrm{E}-13$ \\
\hline 15 & Of & Block AND (CC) & $6.75 \mathrm{E}-12$ \\
\hline 16 & $\mathrm{Pf}$ & Strip AND (CC) & $1.02 \mathrm{E}-12$ \\
\hline 17 & Qf & AC Cable Failure AND (CC) & $6.01 \mathrm{E}-12$ \\
\hline 18 & $\mathrm{Rf}$ & $\begin{array}{l}\text { DC Main Cable Failure AND } \\
(\mathrm{CC})\end{array}$ & $2.23 \mathrm{E}-11$ \\
\hline 19 & ef & Inverter AND (CC) & $1.86 \mathrm{E}-08$ \\
\hline 20 & $\mathrm{cf}$ & Transformator AND (CC) & $9.29 \mathrm{E}-10$ \\
\hline 21 & df & $\begin{array}{l}\text { Power Switch Gear AND } \\
\text { (CC) }\end{array}$ & $1.85 \mathrm{E}-09$ \\
\hline 22 & $\mathrm{Ag}$ & Rack Structure AND Battery & $1.94 \mathrm{E}-08$ \\
\hline 23 & $\mathrm{Bg}$ & $\begin{array}{l}\text { Grounding/Lightning } \\
\text { Protection System AND } \\
\text { Battery }\end{array}$ & $1.29 \mathrm{E}-08$ \\
\hline 24 & $\mathrm{Cg}$ & $\begin{array}{l}\text { Junction Box Bypass Diode } \\
\text { AND Battery }\end{array}$ & $5.38 \mathrm{E}-10$ \\
\hline 25 & $\mathrm{Dg}$ & $\begin{array}{l}\text { Encapsulates Bocor AND } \\
\text { Battery }\end{array}$ & $3.23 \mathrm{E}-09$ \\
\hline 26 & $\mathrm{Eg}$ & Module AND Battery & $1.21 \mathrm{E}-11$ \\
\hline 27 & $\mathrm{Fg}$ & Connector AND Battery & $3.58 \mathrm{E}-10$ \\
\hline 28 & $\mathrm{Gg}$ & Fuse String AND Battery & $5.01 \mathrm{E}-11$ \\
\hline 29 & $\mathrm{Hg}$ & SMU AND Battery & $1.31 \mathrm{E}-09$ \\
\hline 30 & $\mathrm{Ig}$ & Fuse AND Battery & $1.59 \mathrm{E}-11$ \\
\hline 31 & $\mathrm{Jg}$ & DC Switch AND Battery & $1.59 \mathrm{E}-09$ \\
\hline 32 & $\mathrm{Kg}$ & Disconnector AND Battery & $7.95 \mathrm{E}-11$ \\
\hline 33 & $\mathrm{Lg}$ & Metal Sleeve AND Battery & $5.56 \mathrm{E}-13$ \\
\hline 34 & $\mathrm{Mg}$ & Screw AND Battery & $4.79 \mathrm{E}-10$ \\
\hline 35 & $\mathrm{Ng}$ & Stud AND Battery & $5.56 \mathrm{E}-13$ \\
\hline 36 & $\mathrm{Og}$ & Block AND Battery & $1.16 \mathrm{E}-11$ \\
\hline 37 & $\mathrm{Pg}$ & Strip AND Battery & $1.75 \mathrm{E}-12$ \\
\hline 38 & Qg & $\begin{array}{l}\text { AC Cable Failure AND } \\
\text { Battery }\end{array}$ & $1.03 \mathrm{E}-11$ \\
\hline 39 & $\mathrm{Rg}$ & $\begin{array}{l}\text { DC Main Cable Failure AND } \\
\text { Battery }\end{array}$ & $3.84 \mathrm{E}-11$ \\
\hline 40 & $\mathrm{eg}$ & Inverter AND Battery & $3.20 \mathrm{E}-08$ \\
\hline 41 & $\mathrm{cg}$ & Transformator AND Battery & $1.60 \mathrm{E}-09$ \\
\hline 42 & $\mathrm{dg}$ & $\begin{array}{l}\text { Power Switch Gear AND } \\
\text { Battery }\end{array}$ & $3.18 \mathrm{E}-09$ \\
\hline & & Total Probability & 1.21E-07 \\
\hline
\end{tabular}


Table 3. Comparison of Probabilistic Failure Rate and Reliability of Grid and Hybrid Connections

\begin{tabular}{lll}
\multicolumn{1}{c}{ Description } & \multicolumn{1}{c}{ Grid } & \multicolumn{1}{c}{ Hybrid } \\
\hline $\begin{array}{l}\text { Probability Failure } \\
\text { Rate } \mathrm{t}=8.5 \text { hour }\end{array}$ & 0.001219059 & $1.21 \mathrm{X} \mathrm{10^{-7 }}$ \\
\hline $\begin{array}{l}\text { Reliability } \mathrm{t}=8.5 \\
\text { hour }\end{array}$ & $0.9988 / 99.88 \%$ & $0.99 / 99.9 \%$ \\
\hline $\begin{array}{l}\text { Probability Failure } \\
\text { Rate } \mathrm{t}=\text { in 1 year }\end{array}$ & 0.444956517 & 0.016182068 \\
\hline $\begin{array}{l}\text { Reliability t }=\text { in 1 } \\
\text { year }\end{array}$ & $0.555 / 55.504 \%$ & $0.983 / 98.38 \%$ \\
\hline $\begin{array}{l}\text { Probability Failure } \\
\text { Rate } \mathrm{t}=\text { in 20 year }\end{array}$ & 8.8991 & 6.47 \\
\hline $\begin{array}{l}\text { Reliability } \mathrm{t}=\text { in 20 } \\
\text { year }\end{array}$ & $-7.90 / 0 \%$ & $-5.47 / 0 \%$ \\
\hline
\end{tabular}

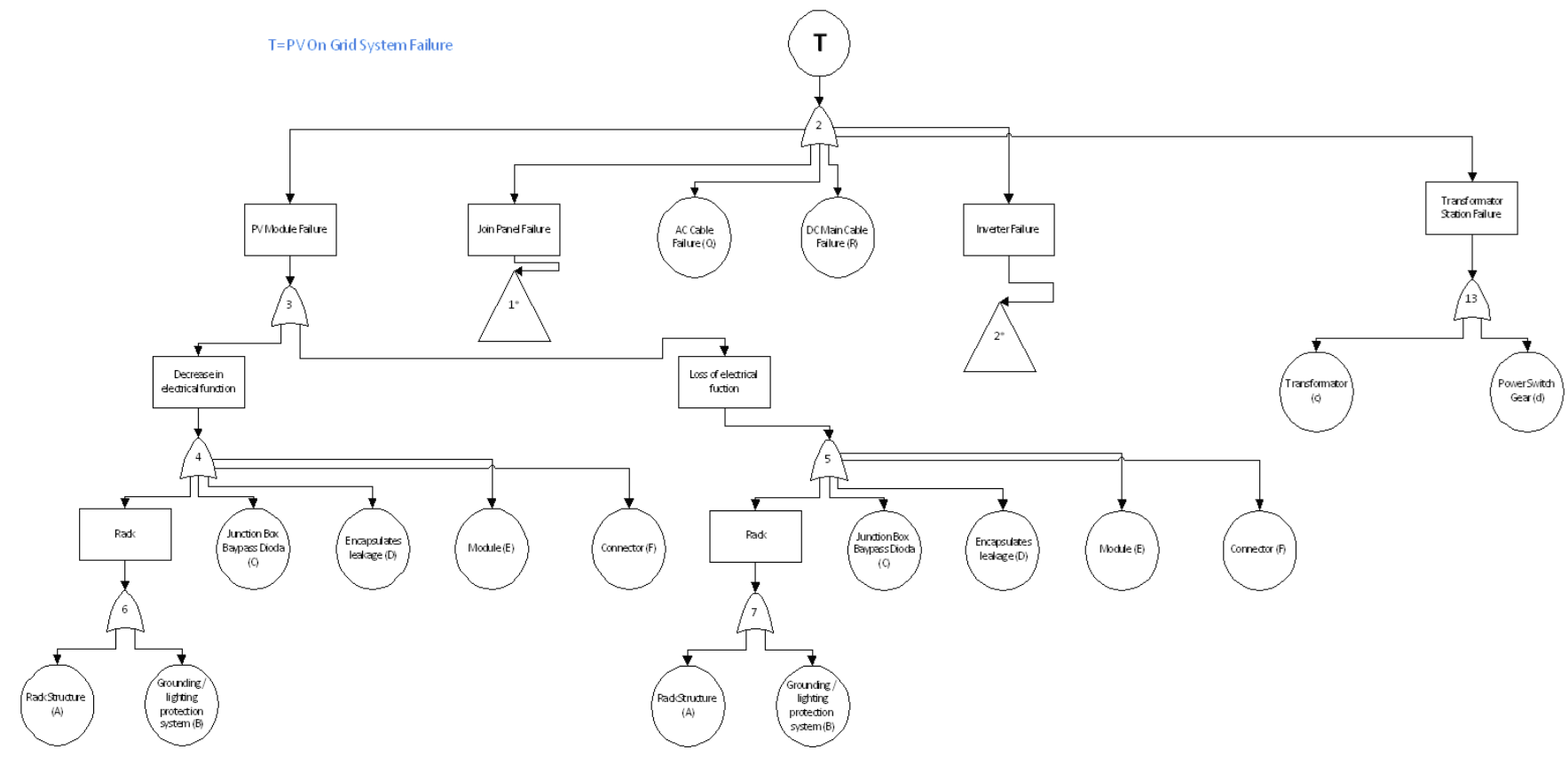

Figure 3. Failure PV on Grid System (Fault Tree Branch 1)

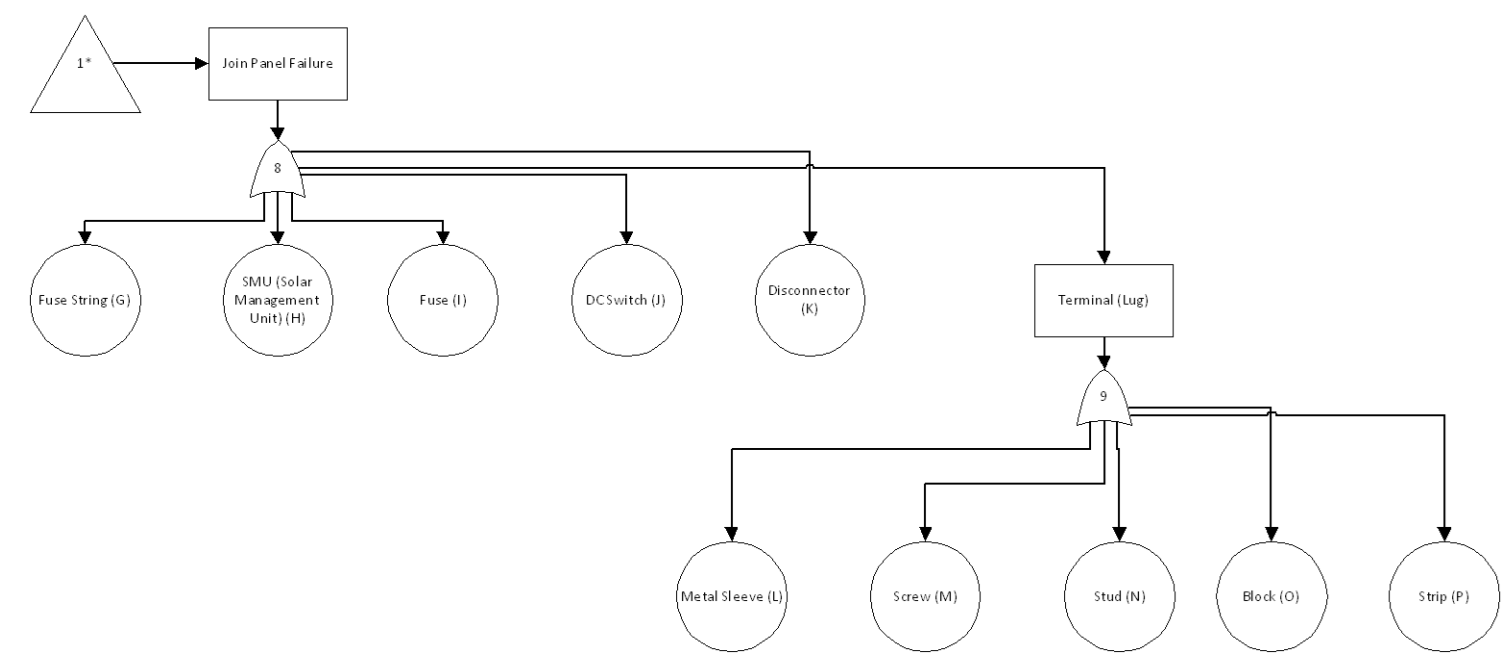

Figure 4. Failure PV on Grid System (Fault Tree Branch 2) 


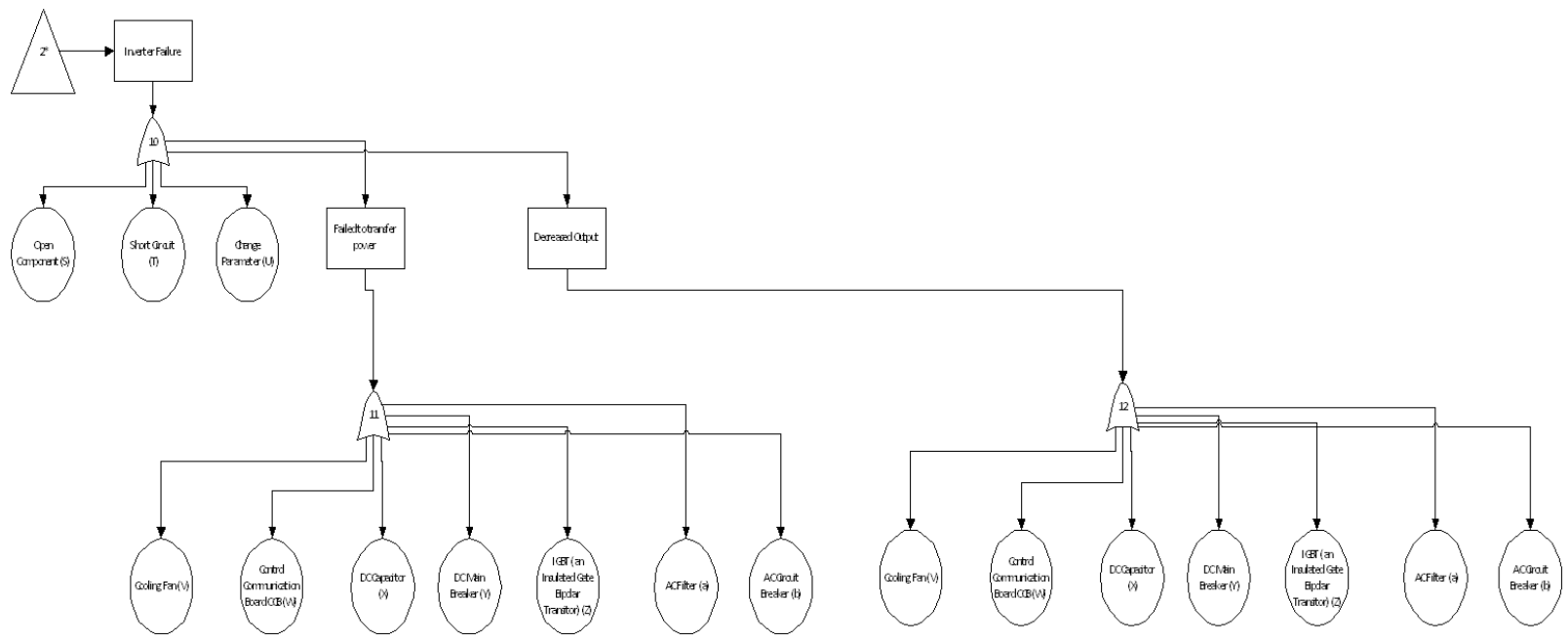

Figure 5. Failure PV on Grid System (Fault Tree Branch 3)

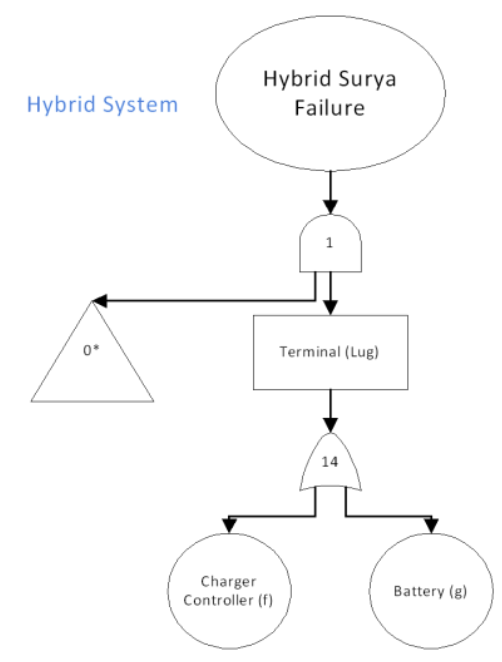

Figure 6. Failure PV Hybrid System (Fault Tree Branch 1)

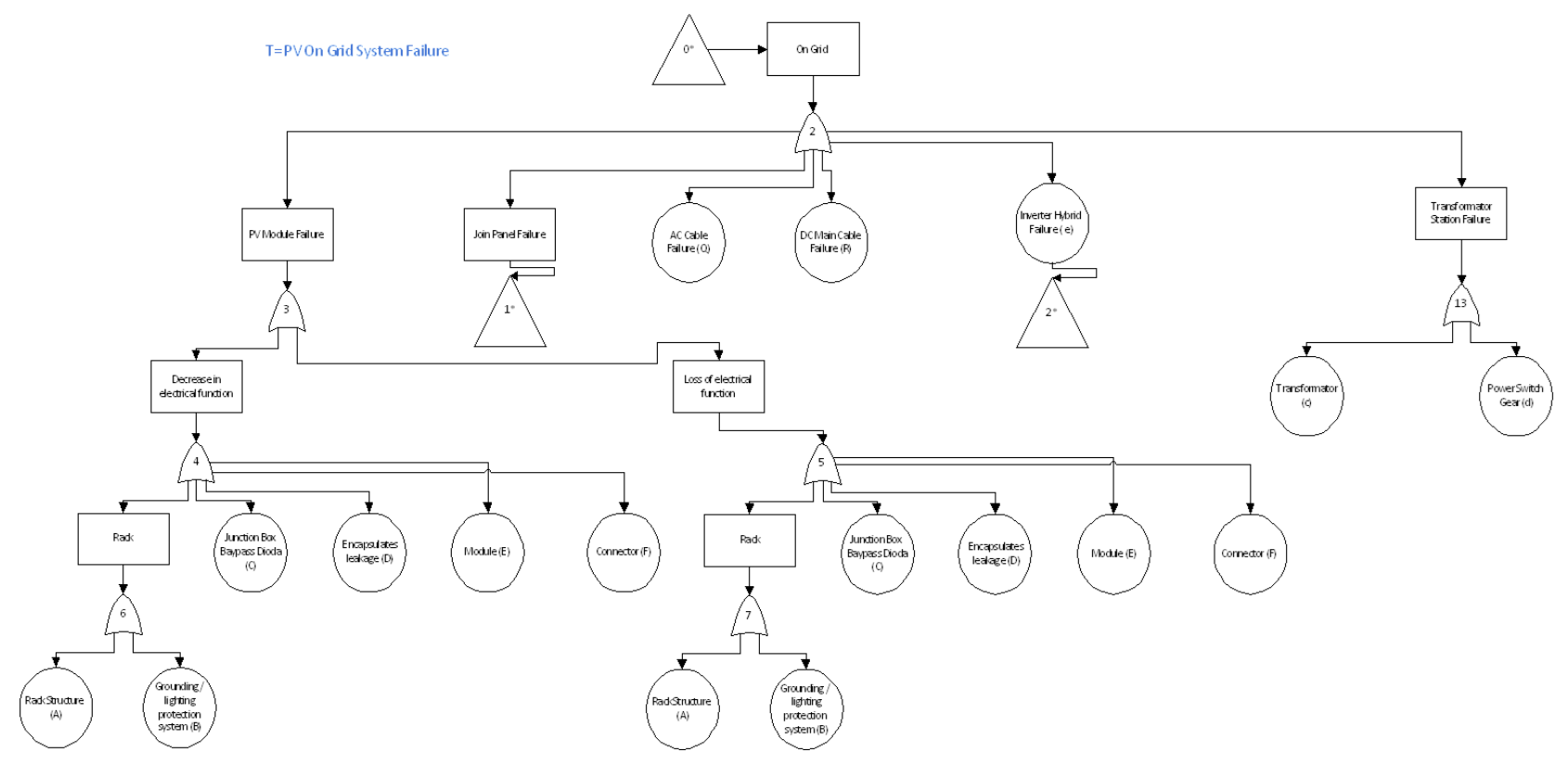

Figure 7. Failure PV Hybrid System (Fault Tree Branch 2) 
In determining the maintenance and replacement schedule, apart from being seen from quantitative calculations, it can be determined based on the component's working age. When it is over the working age, the component's performance will decline. However, this is also influenced by the operation and environmental conditions or other external factors so that when operating, it must also be seen with the operating standards. The working life of each component can be seen from the manual book or component datasheet. Based on the datasheet and quantitative analysis of each element, along with a summary of their working-age and maintenance schedule, the result is shown in Table 4.

Table 4. Component Life and Maintenance

\begin{tabular}{ll}
\hline \multicolumn{1}{c}{ Description } & \multicolumn{1}{c}{ Year } \\
\hline Useful life Solar panel & 20-25 Year \\
\hline Useful life Inverter & $5-10$ Year \\
\hline Useful life MCCB & 30 Year \\
\hline $\begin{array}{l}\text { Useful life Online } \\
\text { Monitoring }\end{array}$ & 15 Year \\
\hline Useful life Battery & $\begin{array}{l}\text { <20 Year, with a battery life } \\
\text { calculation of about 7 years }\end{array}$ \\
\hline Useful life Electric & 30 Year \\
Instrument & 14 Year \\
\hline Useful life Genset & Per 1 year for grounding checks \\
\hline Maintenance & $\begin{array}{l}\text { Per } 5 \text { years for maintenance and } \\
\text { replacement of inverter spare parts }\end{array}$ \\
\hline $\begin{array}{l}\text { per 2 years for instrument and } \\
\text { electrical maintenance }\end{array}$ \\
$\begin{array}{l}\text { Per 1 year for cleaning and } \\
\text { inspection of power modules }\end{array}$ \\
\hline $\begin{array}{l}\text { per 1 - 3 years for replacement of } \\
\text { the generator spare part }\end{array}$ \\
\hline
\end{tabular}

\section{CONCLUSION}

Reliability analysis in a Solar Power Plant system connected on-grid and hybrid can be conducted using a fault tree. The results are used to determine the priority of the components that need improvement, given the ranking with the highest probability of failure. Besides, it can see the system's reliability and its loss during $t$ (time) of operation, which is determined by knowing the value of its failure rate beforehand. After 1 year of operation, the reliability for the On-Grid connection decreased to $55.504 \%$, this value is below that of the $98.38 \%$ hybrid connection. These results can be used as a reference for scheduling improvements or monitoring. Also, to determine the schedule for replacement of spare parts and maintenance, it is necessary to consider the components' life and the operating environment's state, based on a manual book or datasheet. So that failure of Solar Power Plant can be minimized.

\section{ACKNOWLEDGMENT}

The analysis carried out in this study is part of the first author's thesis, where the existing system is part of the Master Plan project for offices in the Wonogiri area. For this reason, the authors would like to thank the Wonogiri government and other people who have helped the author in this project.

\section{REFERENCES}

[1] P. M. Dauenhauer, D. Frame, A. Eales, S. Strachan, S. Galloway, and H. Buckland, "Sustainability evaluation of community-based, solar photovoltaic projects in Malawi," Energy. Sustain. Soc., vol. 10, no. 1, 2020.

[2] Köntges M. et al., IEA-PVPS T13-01 2014 Review of Failures of Photovoltaic Modules, July. 2014.

[3] G. Zini, C. Mangeant, and J. Merten, "Reliability of largescale grid-connected photovoltaic systems," Renew. Energy, vol. 36, no. 9, pp. 2334-2340, 2011.

[4] A. Sayed, M. El-Shimy, M. El-Metwally, and M. Elshahed, "Reliability, availability and maintainability analysis for grid-connected solar photovoltaic systems," Energies, vol. 12, no. 7, 2019.

[5] C. Nemes, F. Munteanu, M. Rotariu, and D. Astanei, "Availability assessment for grid-connected photovoltaic systems with energy storage," Proc. 2016 Int. Conf. Expo. Electr. Power Eng. EPE 2016, no. Epe, pp. 908-911, 2016.

[6] S. Kanata, "Kajian Ekonomis Pembangkit Hybrid Renewable Energi Menuju Desa Mandiri Energi di Kabupaten Bone-Bolango," J. Rekayasa Elektr., vol. 11, no. 2, 2015.

[7] S. Baschel, E. Koubli, J. Roy, and R. Gottschalg, "Impact of component reliability on large scale photovoltaic systems' Performance," Energies, vol. 11, no. 6, 2018.

[8] E. S. H and U. B., "Analisa Keandalan Sistem Bahan Bakar Motor Induk Pada Km. Leuser," Kapal, vol. 5, no. 2, pp. 123-135, 2012.

[9] C. Liu, "Research and application of computer aided analysis and optimization algorithm for fault tree," Proc. 2017 Int. Conf. Comput. Technol. Electron. Commun. ICCTEC 2017, vol. 0, pp. 380-383, 2017.

[10] D.Priyanta, "Keandalan Dan Perawatan," Surabaya,2015

[11] D. X. Gao, J. J. Hou, K. Liang, and Q. Yang, "Fault diagnosis system for electric vehicle charging devices based on fault tree analysis," Chinese Control Conf. CCC, vol. 2018-July, pp. 5055-5059, 2018.

[12] G. Greeff and R. B. T.-P. E.-M. and S. C. M. Ghoshal, Eds., "8 - Production capability management," Oxford: Newnes, pp. 214-242. 2004.

[13] R. B. Waghmode, L. Y.; Patil, "An Overview of Fault Tree Analysis ( Fta ) for Reliability Analysis," J. Eng. Res. Stud., vol. IV, no. March 2013, pp. 06-08, 2016.

[14] W. E. Vesely, F. F. Goldberg, N. H. Roberts, and D. F. Haasl, "Fault Tree Handbook (NUREG-0492)," U.S. Nucl. Regul. Com., p. 209, 1981.

[15] A. Colli, "Failure mode and effect analysis for photovoltaic systems," Renew. Sustain. Energy Rev., vol. 50, pp. 804-809, 2015.

[16] Adrianti, "Evaluasi keandalan pembangkit listrik tenaga surya yang terhubung ke grid," J. Nas. Tek. Elektro, vol. 5, no. 2 December, 2016.

[17] L. Yun, Y. Bofeng, Q. Dan, and L. Fengshuo, "Research on Fault Diagnosis of Photovoltaic Array Based on Random Forest Algorithm," in 2021 IEEE International Conference on Power Electronics, Computer Applications (ICPECA), 2021, pp. 194-198. 